\title{
The Degree of Smoking for Out Patient with COPD in Padang
}

\author{
Dita Hasni ${ }^{1}$, Nilas Warlem ${ }^{2}$ \\ \{ditahasni@fk.unbrah.ac.id\} \\ Department of Pharmacology Faculty of Medicine, Baiturrahmah University, Padang ${ }^{1}$ \\ Department of Pulmonology Faculty of Medicine, Baiturrahmah University, Padang ${ }^{2}$
}

\begin{abstract}
Chronic Obstructive Pulmonary Disease (COPD) is an air flow inhibition disease that often occurs in cigarette exposure to active or passive smokers. Indonesia is one of the developing countries that have a high number of active smokers. The purpose of this study was to determine the level of smoking in COPD patients in the city of Padang. This observational descriptive study was conducted by interviewing COPD patients who were admitted to Dr. Rashidin Lung General Hospital and Reksosudiryo Army Hospital. Data is taken from May to September 2018. Data is processed manually and presented in the form of a frequency distribution table. A total of 53 subjects were included in this study after signing written informed consent and found the Brinkman index value was heavy at $47.2 \%$, moderate at $22.6 \%$ and mild at $30.2 \%$. In this study, it can be concluded that the highest percentage of COPD patients is heavy smokers.
\end{abstract}

Keywords: Brinkman Index, COPD, Smoking.

\section{Introduction}

Chronic obstructive pulmonary disease (COPD) is a progressive inflammatory disease of the lungs characterized by chronic bronchitis, airway thickening and emphysema [1]. It is a significant cause of morbidity and mortality in countries at all levels of economic development by smoking which is recognized as the most important causative factor [2]. According to WHO estimates, 80 million people in the world have moderate to severe COPD [3]. The prevalence of COPD in Indonesia from 2013 Riskesdas data shows 3.7 per 100 population and in West Sumatra 3 per 100 inhabitants [4].

Cigarette smoke contains many highly toxic chemicals [5]. Carbon monoxide (CO) is one of the main poison gases. Increased CO levels in the body due to exposure to cigarettes both active and passive smokers are associated with increased oxidative stress and heme oxygenase (HO) that respond to conditions in which oxidative stress increases [6,7].

Cigarettes produce reactive oxidants which induce inflammation in the central airways, peripheral airways and pulmonary parenchyma. Research has shown that in bronchial biopsies obtained from the central airways, smokers experience chronic inflammatory changes, with an increase in the number of specific types of inflammatory cells in various parts of the lungs, and structural remodeling due to damage by exposure and constant repair $[3,8]$.

Based on the above literature states that cigarette exposure plays a role in the incidence of COPD, therefore this study was conducted with the aim of finding out the description of smoking rates for out-patients with COPD in Padang. 


\section{Methods}

This study was conducted in May-September 2018 at the RSUD dr. Rashidin and RST Reksowidiryo, Padang. 53 subjects were included in this descriptive study and were willing to be interviewed after being given an explanation and signing the written informational in writing. Subjects are those with Chronic Obstructive Pulmonary Disease who have been diagnosed by pulmonologists and are undergoing outpatient therapy.

Smoking rates were assessed using the Brinkman index by calculating the number of cigarettes smoked per day and how long to smoke in a year. Brinkman Index value is classified as a mild smoker if $<200$, moderate smoker if $200-599$ and heavy smoker if $\geqq 600$ [9].

\section{Results}

Table 1. Distribution of Research Subjects by Gender

\begin{tabular}{lll}
\hline Gender & N & \% \\
\hline Men & 49 & 92.5 \\
Women & 4 & 7.5 \\
\hline Amount & 53 & 100 \\
\hline
\end{tabular}

Table 1. shows that in the study subjects the highest percentage of patients with COPD was dominated by men as many as 49 people $(92.5 \%)$.

Table 2. Distribution of Research Subjects by Age

\begin{tabular}{lll}
\hline Age (years) & N & \% \\
\hline $40-49$ & 4 & 7.5 \\
$50-59$ & 14 & 26.5 \\
$\geq 60$ & 35 & 66 \\
\hline Total & 53 & 100 \\
\hline
\end{tabular}

Table 2. shows that the highest percentage of research subjects in the age group $\geq 60$ year is 35 people $(66 \%)$.

Table 3. Distribution of research subjects based on smoking

\begin{tabular}{lll}
\hline History of Smoking & N & \% \\
\hline Active Smokers & 43 & 81.1 \\
Passive Smokers & 10 & 18.9 \\
\hline Total & 53 & 100 \\
\hline
\end{tabular}

Tables 3. shows that COPD patients in this study were predominantly active smokers of 43 people $(81.1 \%)$. 
Table 4. Distribution of Research Subjects by Smoking Level Smoking

\begin{tabular}{lll}
\hline Rate (IB) & N & \% \\
\hline Mild & 16 & 30.2 \\
Moderate & 12 & 22.6 \\
Weight & 25 & 47.2 \\
\hline Total & 53 & 100 \\
\hline
\end{tabular}

In Table 4. shows that the highest percentage of subjects in this study were heavy smokers as 25 people $(47.2 \%)$.

\section{Discussion}

Characteristics of the sample in this study are seen from gender and age. Based on gender, patients with COPD are dominated by men with a percentage of $92.5 \%$. This finding is consistent with the results of the study by Naser and Nugraha who obtained data that COPD patients were predominantly male with a percentage of $100 \%[9,10]$. But in this study there were groups of women who suffered COPD as much as $7.5 \%$. This is in accordance with the study in Taiwan which reported the risk of men suffering from COPD $1.42 \mathrm{x}$ greater than women [11]. Gender differences in the incidence of COPD occur because smoking is more prevalent in the male compared to female groups [12]. According to data Riskesdas 2018, men smoke as much as $62.8 \%$ and women smoke $4.8 \%$ of the total population [13]. Other factors that influence gender differences in the incidence of COPD in addition to the frequency of exposure to cigarette smoke are different lung functions between gender groups, reported from the Soreihm study that female lung function was lower than men in the group who were low in exposure to smoke $[12,14]$.

The age group with the highest percentage in this study is a group of 60 years and above, as many as 35 people (66\%), and only 4 people (7.5\%) are less than 50 years old. This is consistent with Naser's research which states that the highest age group of COPD patients is 60 years and above with a proportion of 55\% [10]. This study is also consistent with the results of a study in Taiwan which reported COPD sufferers dominant at age $>60$ years and followed by an increase the risk is 6.53 times compared to the age of 40-49 years [11]. Other studies report the same thing that the population aged $>75$ years in US $10 \%$ suffers from COPD [15]. These results are associated with a decrease in lung function which decreases faster in people who continue to smoke at the age of more than 45 years $[7,16,17]$.

In this study, data on active smokers was $81.1 \%$ and passive smoking was $18.9 \%$. This result is supported by the literature which states that smoking is a major risk factor for someone suffering from COPD [1]. The higher the level of someone smoking, the more people will be exposed to various substances that are considered toxic by the body in the respiratory tract which will cause more pulmonary function faster than non-smokers $[3,8]$. A person who does not smoke can also suffer from COPD due to other risk factors such as exposure to pollution in the workplace [18], pollution in the household due to exposure to smoke during cooking [19] and can also be due to passive smoking [20,21].

In this study, COPD patients were dominated by subjects with a severe Brinkman index of $47.2 \%$. The research data is not much different from the research conducted by Nugraha which obtained $45 \%$ of the Brinkman index data [9]. other similar studies reported a linear relationship between> 30 years of smoking and COPD [16]. The findings in this study are slightly different 
from the Xavier 2014 report which obtained data on COPD patients in the heavy smokers group of $36 \%$ and the highest in the moderate group by $45.3 \%$. In this study it was also reported that smoking could interfere with mucosile clearance and associated with the intensity of smoking [6].

\section{Conclusion}

In Patients with Chronic Obstructive Pulmonary Disease in Padang City, the majority of cases were men, active smokers with the Brinkman index $\geq 600$

\section{References}

[1] Brashier BB, Kodgule R.: Risk Factors And Pathophysiology Of Chronic ObstructivePulmonary Disease (COPD). J Assoc Physicians India. pp. 17-21 (2012)

[2] Adair T, Hoy D, Dettrick Z, Lopez AD.: 100 Years Of Mortality Due To Chronic Obstructive Pulmonary Disease In Australia: The role of tobacco consumption Vol. 16(12), pp. 1699-705. Int J Tuberc Lung Dis (2012)

[3] Laniado-Laborin R.: Smoking And Chronic Obstructive Pulmonary Disease (COPD). Parallel Epidemics Of The 21st Century. Vol. 6, pp. 209-24. International Journal of Environmental Research and Public Health (2009)

[4] RISKESDAS. Riset Kesehatan Dasar. Jakarta (2013)

[5] Hu G, Zhou Y, Hong W, Tian J, Hu J, Peng G, et al.: Development And Systematic Oxidative Stress Of A Rat Model Of Chronic Bronchitis And Emphysema Induced By Biomass Smoke. Vol. 39(6), pp. 229-40. Exp Lung Res (2013)

[6] Xavier RF, Ramos D, Ito JT, Rodrigues FMM, Bertolini GN, Macchione M, et al.: Effects Of Cigarette Smoking Intensity On The Mucociliary Clearance Of Active Smokers. Vol. 86(6), pp. 479-85. Respiration (2014)

[7] Riesco JA, Alcázar B, Trigueros JA, Campuzano A, Pérez J, Lorenzo JL.: Active Smoking And COPD Phenotype: Distribution And Impact On Prognostic Factors. Vol. 12(19), pp. 89-99. Int J COPD (2017)

[8] Tamimi A, Serdarevic D, Hanania NA.: The Effects Of Cigarette Smoke On Airway Inflammation In Asthma and COPD: Therapeutic Implications. Vol. 106, pp. 319-28. Respiratory Medicine (2012)

[9] Nugraha I.: Hubungan Derajat Berat Merokok Berdasarkan Indeks Brinkman Dengan Derajat Berat PPOK. Vol. 53(9), pp. 1689-99. Akper Patria Husada Surakarta (2013)

[10] Naser F, Medison I, Erly.: Gambaran Derajat Merokok Pada Penderita PPOK di Bagian. Vol. 5(2), pp. 306-11. J Kesehat Andalas (2016)

[11] Su-Lun H, Yu-Ching L, Su-Er G, Miao-Ching C, Chiang-Ting C, Chieh-Mo L.: Prevalence of Chronic Obstructive Pulmonary Disease in Soutwestern Taiwan: a Population-Based Study. Vol. 3(2), pp. 2-5. Int J Respir Pulm Med (2016)

[12] Sørheim IC, Johannessen A, Gulsvik A, Bakke PS, Silverman EK, DeMeo DL.: Gender differences in COPD: Are Women More Susceptible To Smoking Effects Than Men?. Vol. 65(6), pp. 480-5. Thorax (2010)

[13] Kemeneterian Kesehatan RI.: Hasil Utama Riskesdas Tahun 2018. Jakarta (2018)

[14] Peter J Barnes.: Sex Differences in Chronic Obstructive Pulmonary Disease Mechanism. Vol. 193(15). Am J Respir Cell Mol Biol (2016)

[15] G. Paolisso.: COPD In Elderly Patients. Vol. 64(1), pp. 117-8. J Gerontol Geriatr (2016)

[16] Liu Y, Pleasants RA, Croft JB, Wheaton AG, Heidari K, Malarcher AM, et al.: Smoking Duration, Respiratory Symptoms, And COPD In Adults Aged 45 Years With A Smoking History. Vol. 10(14), pp. 09-16. Int J COPD (2015) 
[17] Cortopassi F, Gurung P, Pinto-Plata V.: Chronic Obstructive Pulmonary Disease in Elderly Patients. Vol. 33(4), pp. 539-52. Clin Geriatr Med (2017)

[18] Mahmood T, Singh R, Kant S, Shukla A, Chandra A, Srivastava R.: Prevalence And Etiological Profile Of Chronic Obstructive Pulmonary Disease In Nonsmokers. Vol. 34(2), pp. 122. Lung India (2017)

[19] Ngahane BHM, Ze EA, Chebu C, Mapoure NY, Temfack E, Nganda M, et al.: Effects of Cooking Fuel Smoke On Respiratory Symptoms And Lung Function In Semi-Rural Women In Cameroon. Vol. 21(1), pp. 61-5. Int J Occup Environ Health (2015)

[20] Salvi SS, Barnes PJ.: Chronic Obstructive Pulmonary Disease In Non-Smokers. Vol. 374(9691), pp. 733-43. Lancet (2009)

[21] Hasni D, Nilas W. Proportion of Non-smokers in Cases of Chronic Obstructive pulmonary Disease in Padang City West Sumatra Department of Pharmacology, Faculty of Medicine, Baiturrahmah University, Padang, West Sumatra. Vol. 5(11). pp. $4182-4$ (2018) 